\title{
The Importance of Rain Water Harvesting Ponds as a Solution for the Problem of Water Scarcity in the Dry Zone in Sri Lanka-A Study Based on Thanamalwila DSD Division
}

\author{
G.M. Bandaranayaka, T. Kandambige ${ }^{*}$, R.N. Gamachchige \\ Department of Geography, University of Sri Jayawaradanapura, Sri Lanka \\ *tisara90@gmail.com
}

\begin{abstract}
Generally, drought is a regular event in Sri Lanka, where most part of the year experiences scarcity of water for a considerable time period. It is evident that, in the Yala season (MaySeptember), the entire dry zone is highly vulnerable to dry spells or occasionally drought conditions. Not only drought but also are dry spells serious problem setback the economic and status of that region.

In the dry zone the most vulnerable drought affected areas are Monaragala, Vauniya, Hambantota and Polonnaruwa. Most of these areas, agriculture is practiced with rainfall and irrigation water supply. In Anuradhapura, small tank irrigation and large scale irrigation projects have been established to overcome seasonal water scarcity. However, in Monaragala, such water systems are limited. Most prominent agriculture systems are chena cultivation and home gardens. Climatically this area receives of high rainfall from October to November, while the water is scarce in the rest of the year. In order to overcome the agriculture problems, many water utilisation systems have been established by government and NGO's such as World Vision. Rain water Harvesting Pond systems (RWHP) is one of them. This research examined how far the RWHP system has been successful to solve the farmer's water problems taking Thanamalwila as the sample. The methods of data collection were questionnaires, structured interviews, in-depth and open ended interviews and key informer interviews. Focus group discussion and general observations were done to identify the environmental condition such as small tanks, soil water, ground water, vegetation and streams. Formal interviews were done with selected 100 frames who utilized RWP. It was found that related to RWHP system, $100 \%$ water utilisation was for agriculture. Most farmers use RWHP for multiple purposes such as vegetation cultivation, domestic use of water and animal husbandry. Success is highly dependent on the location of ponds and some ponds are active throughout of the year. According to water availability in the stream, some are active only for a limited period because surface water storage is very limited.
\end{abstract}

Keywords: Drought, Ground water, Irrigation system, Rain water harvesting ponds, Water utility. 